\title{
The Ethical Project of Cultural Translation
}

\author{
SHARMANI PATRICIA GABRIEL \\ Department of English, Faculty of Arts and Social Sciences, Universiti Malaya, \\ 50603 Kuala Lumpur, Malaysia \\ spgabriel@um.edu.my
}

Published online: 20 October 2020

To cite this article: Sharmani Patricia Gabriel. 2020. The ethical project of cultural translation. KEMANUSIAAN the Asian Journal of Humanities 27(2): 103-121. https://doi.org/10.21315/ kajh2020.27.2.6

To link to this article: https://doi.org/10.21315/kajh2020.27.2.6

\begin{abstract}
This article is a revised and expanded version of the author's plenary address for the Fifth International Conference on Linguistics, Literature and Culture (ICLLIC 2019) convened by the School of Humanities, Universiti Sains Malaysia, Pulau Pinang, Malaysia. It engages with the conference theme of globalisation and cultural change by reflecting on translation as an ethical project. It argues that the problematic of postcolonial translation is also a significant site to address issues of social justice and the unequal power relations between linguistic and cultural systems, especially in the context of the homogenising forces of globalisation. Disrupting normative views that one should aim for "sameness" between source and target texts, or between "original" and "translated" cultures, if translation is to be deemed a project of equal exchange between cultures and languages, the article asserts that the task of the postcolonial translator is not to preserve equivalence of meaning but to jolt the reader with moments of deep estrangement and unfamiliarity. Such a strategy will confront the reader with the reality of cultural difference. Indeed, the "global cultural consciousness" that ICLLIC 2019 called for demands that we go beyond the communicative model of translation to a more contemplative and contingent model of "carrying across" that affirms and respects difference. In short, the article argues that translation might provide the provocation for ethical ways of knowing the other.
\end{abstract}

Keywords and phrases: cultural translation, ethics of translation, Walter Benjamin, Homi Bhabha, postcolonialism, Bangsa Malaysia

\section{Introduction}

This article reorients critical attention to the concept of translation as an ethical project. One of its implicit objectives, in being attentive to the ethical perspective to translation, is to reassess the relationship between the "original" and its "copy", both of which are tropes that have long underpinned approaches to the study of 
translation. Such a relationship is embedded, for example, in the imperial project of colonial expansion, as well as its politics of representation, culture and identity, that had automatically and for so long conferred upon Europe the status of the "original". This elevated position or status of Europe or "the West" as the "original" came with the corollary power to fix and regulate the identities of their inferior "copies". Colonies were thus "translated" in tandem with the "civilising" and universalising impulses inherent in colonialist and other imperialist discourses.

The postcolonial interrogation of hegemony and universality that followed from such a relationship between the centre and its margins, the "original" and its "copies" or "translations", had as its main objective the task of reclaiming and rewriting the histories and literary traditions of those languages and peoples marginalised and dehistoricised by hegemonic discourses and normalising assumptions. Such a critical reorienting of translation and its founding suppositions led to a situation where translation began to be seen by scholars as a project of political engagement that could offer a new paradigm or problematic for the postcolonial condition (see, for example, Tymoczko 1999). This was also articulated earlier by Tejaswini Niranjana in her book, Siting Translation: History, Post-Structuralism and the Colonial Context (1992), which draws on colonial history and poststructuralist theory to point to the asymmetrical power relations between the cultures of the coloniser and the colonised. Niranjana $(1992,1)$ argues that,

[i]n a post-colonial context the problematic of translation becomes a significant site for raising questions of representation, power and historicity. The context is one of contesting and contested stories attempting to account for, to recount, the asymmetry and inequality of relations between peoples, races, languages.

Although it was necessary and continues to be necessary for postcolonial societies to appropriate the project of translation by "writing back" to the imperial centre in the effort to reclaim their histories and their own literary traditions and languages, I suggest that it would also be productive when considering the politics of identity and recognition provided to us by the model of translation to read this in conjunction with translation's often overlooked ethical imperatives. Toward this end, I will draw from Walter Benjamin's critique of traditional translation theory in his canonical essay, "The Task of the Translator" (1923). Also important for me in this effort is Bhabha's complementary ideas on translation and his extension of Benjamin's insights into postcolonial contexts and concerns in The Location of Culture (1994). I will also examine some theoretical starting-points advanced by Jacques Derrida and Stuart Hall, suggesting how their ideas, directly or indirectly, bear relevance to the concerns of postcolonial translation studies. 
I argue that the ethics of translation can also become a significant site to address issues of social justice and the unequal power relations between language and cultural systems, especially in the context of the unequal flows and forces of globalisation. In a world of increasing diversity but also competing imaginations, any concept that unsettles the primacy of the original and the binary terms built into the original-copy relationship is of particular salience. The key point here is that there is a politics and ethics to translation that we would do well to recognise. We can even go so far as to say that translation might provide the provocation for ethical ways of knowing the other.

In this context, the assertion made by scholars such as Niranjana $(1992,46)$ that postcolonial translation can "reinvent oppositional cultures in nonessentialising ways" is of special significance. It is important to note in this regard that such scholars were implicitly expressing a rejection of the communicative model and purpose of translation. Aspiring for communicative accuracy in translation, according to this perspective, was tantamount to a rejection of historicity and selfreferentiality.

As an attempt, then, to rethink the relationship between the original and its translation in ethical terms, this article relies on Benjamin's questioning of the hierarchies in the communicative model of translation but also extends this discussion to postcolonial contexts and processes of diaspora, nationalism and cultural identity formation.

\section{Mapping Translation}

It would perhaps be useful to first provide an overview and a necessarily cursory one at that, of the project and practice of translation as the term is understood differently by translation studies scholars and translators. As a literary practice, translation has existed for centuries but the systematic study of translation as an academic subject is a recent phenomenon. Traditionally, translation was seen as a subfield of linguistics, on the grounds that translation basically entailed a transaction between two languages, that is, as comprising a substitution of target language meanings for source language meanings. Thus, in the early stages of translation practice, translation was defined as a descriptive exercise that involved replacing a text in one language by another in a different language, with the two texts having approximately the same meaning. Equivalence in meaning was prioritised; the main emphasis in descriptive translation studies was the linguistic and semantic aspects of translation. In other words, translation was perceived as a binary phenomenon: as there are always two elements in a translation exercise, an 
original language and its secondary production in another language, the aim was to achieve sameness of meaning between both languages.

In traditional discussions, then, items that proved particularly intractable to translation were often described as being "culture-specific" - for example, dhoti, roti, karma or maya. Such items are seen to be innately "Indian" for they do not correspond exactly to the Western "trousers", "bread", "deeds, both past and present" or "illusion". Or the Arabic word souk that is not the same as the English word "market"; the two words suggest two quite different activities of buying and selling. The Malay word kampung, as yet another example, conjures a sense of place that does not quite capture the meaning conveyed in the English equivalent, "village". These culture-specific words are either omitted in the English-language translation or replaced by readily available equivalents in the interest of upholding the norm of readability and fluency of the target readership over and above safeguarding the distinctive identity of the source language. Such a paradigm of translation avoids efforts for its readers, minimising the differences between their own world and that of the source text.

As a field of study, translation studies began to flourish in the late 1970s and the publication of Translation Studies by Susan Bassnett in 1980 further crystallised the importance of this emergent discipline by providing an overview of some of the key themes and preoccupations of this field, including a history of translation theory and some of the problems associated with the translation of literary and linguistic phenomenon. By this time, as the book observes, translation had moved from a preoccupation with the domain of language or linguistics to that of the text.

It then also began to be noticed that literary texts were constituted not primarily of language or texts but in fact of culture, language being in effect a medium for the transmission of that culture. Thus, the new argument was that translations do not only include lexical content and syntax, but also ideologies and cultural values.

There was the corollary realisations that not only were particular words culturespecific but indeed the whole language was specific to the particular culture it belonged to or came from, to some degree or the other. The Sapir-Whorf hypothesis, which expounded the belief that a language defined and delimited the particular world-view of its speakers, in the sense that what they could not say in their language was what they could not even conceive of, supported the view that the specificity of a culture was coterminous with the specificity of its language. The argument was that different languages offered different conceptual meanings of the world. Though the aspects of determinism in this hypothesis (that we are all "locked into" our own cultural perspectives or conceptual maps) have 
come under criticism (see, for example, Hyde 1993), what is useful is the notion of "untranslatability" that the hypothesis implicitly advances. As different languages see the world differently, untranslatability emerges when no exact equivalent can be found in the target language for a word from the source language, examples of which include the culture-specific words mentioned earlier.

In the 1990s, then, translation became to be seen as a transaction not only between two languages, as in the traditional theory of translation, but rather a more complex negotiation between two cultures. The unit of translation was no longer a word or a sentence or a paragraph or a page or a text, or indeed even the whole language but the culture in which that text was constituted. As Bassnett and Lefevere famously declared in a jointly written chapter in the book, Translation, History, Culture: A Sourcebook $(1992,8)$, "neither the word, nor the text, but the culture becomes the operational 'unit' of translation". This perspective to the literary text ushered in the "cultural turn", which signalled a shift in the focus of translation studies from linguistics to a broader cultural context. Context was privileged over text and attention was no longer on issues of fidelity of meaning and equivalence but on extra-textual and ideological matters.

The assertion that the literary text does not exist outside of but is deeply implicated in its cultural and ideological contexts informed my own Master's degree thesis, which explored the ways in which the Indian novelist and philosopher Raja Rao worked to "Indianise" both the novel form, a genre that was not traditional to India and the English language. His first novel, Kanthapura (1938), is told in the form of an "interminable" story with multiple digressions and is set in a small village in South India during the tumultuous period of the Gandhian-led nationalist struggle for independence from British rule. Rao's choice of the illiterate and loquacious Brahmin grandmother, Achakka, the revered village story-teller, as his first-person narrator is an important strategy that allowed him to experiment both with the English language and the structure of his novel. It is important to note that Kanthapura is not a translated text; it was originally written in English with a performative attempt to transfer speech, syntactical and other structural patterns characteristic of the regional Indian language of Kannada and the form of storytelling based on the Hindu tradition of the sthalapurana (legendary history) into English. Rao's mode of transcreation (rather than translation as the novel's original language is English) entailed bending and manipulating the English language to accommodate different manners of meaning and "telling", by including the speech patterns, inflections and syntactical structures of an Indian language as it is spoken locally and also by "marking" and infusing English with Hindu spiritual poetics, symbolisms, idioms, kinship and caste terms, forms of address and mythological, religious and literary references. The desired end result of Rao's approach to 
transference through transcreation of cultural meaning demonstrates that although the novel is written in the English language, the cultural codes and conceptual meanings that are transmitted or brought into representation in English are not "quite" English.

Rao's model of transcreation approximates a mode of cultural translation that sought to retain the element of difference and constituted a primary means in the novel's overall strategy to not only subvert the hierarchical relationship between the linguistic and cultural worlds represented by English and Kannada but also to reinvent these relations in a decolonising context. In his now iconic preface to the novel, Rao declares that it is the author's responsibility to convey in a language that is not historically one's own, "the spirit" that is one's own. However, as he was also acutely conscious of the interventions of history, Rao argued that "we cannot write like the English. We should not. We cannot write only as Indians. Our method of expression [...] has to be a dialect which will some day prove to be as distinctive and colourful as the Irish and the American. Time alone will justify it" $(1938, v)$.

Rao's ideological assertion that Indians "cannot write only as Indians" and that they also "cannot [and should not] write "like the English"" compelled him to create an innovative and "distinctive" language that aimed to capture the cultural sensibility of his characters. Though grammatical in all respects, the novel's language is not conventional English and yet not identifiably Indian either, as evidenced in the novel's opening lines:

Our village-I don't think you have ever heard of it-Kanthapura is its
name and it is in the province of Kara. High on the Ghats is it, high up the
steep mountains that face the cool Arabian seas, up the Malabar coast is
it, up Mangalore and Puttur and many a centre of cardamom and coffee,
rice and sugarcane. Roads, narrow, dusty, rut-covered roads, wind
through the forests of teak and of jack, of sandal and of sal and hanging
over bellowing gorges and leaping over elephant-haunted valleys, they
turn now to the left and now to the right... (Rao 1938,1)

The novel's "not-quite English and not-quite Indian" medium is a language of in-betweenness that attempts to mediate two different cultural systems. Although Kanthapura was published in 1938, when India was still a British colony and a time when English would have been the language, as Rao described it, of one's "intellectual makeup [...] [and] not our emotional makeup", his Preface anticipated many of the claims of cultural affinity with and ownership of the English language, on one's own "emotional" terms as well, that were made decades later by postcolonial novelists such as Salman Rushdie and Arundhati Roy. These debates continue 
to reverberate in other former colonies, such as Malaysia and Singapore, where postcolonial assertions of cultural identity are predicated on claims that English has been localised enough to have on-the-ground cultural purchase. Indeed, it is now possible to argue that Malaysian literature in English is a site of production and cultural translation that allows novelists and other creative writers and the scholars who study them, to take control of the terms of representation and challenge elite historiography and other nationalist discourses of cultural exclusion.

\section{Cultural Translation as Process}

There is yet another form of translation where it is not only languages and cultures that are being transformed as they are translated or transmitted from one language or culture to another, both by acquiring new forms and by transforming the linguistic systems of the cultures with which they come into contact. This paradigm of translation attaches significance to the movement of people and their subjectivities and cultural identities. "Cultural translation", as this mode of translation is referred to and defined by Bhabha, offers us a way to understand culture as a process in which there is no start "text" and no fixed target "text", especially relevant in a context characterised by global and migratory flows. In advancing this processual understanding of translation, cultural translation challenges the descriptive paradigm of translation, which generally views translation as a binary phenomenon involving a linear transaction between two polarities, that is, a transfer of meaning from one cultural unit to another. The focus is on the process rather than the product of translation. The primary context of cultural translation is the movement of people as subjects rather than the movement of texts as objects.

As a concept that allows for a focus on the process of translation rather than the materiality of the translated product or object, cultural translation, for Bhabha, constitutes the "third space", a space for indeterminacy, hybridity, subversion, heresy and blasphemy, among other border-crossing transgressions. In his chapter "How Newness Enters the World: Postmodern Space, Postcolonial Time and the Trials of Cultural Translation" (in The Location of Culture), Bhabha elaborates that the third space is a space of movement and ongoing cultural processes, which by traversing clearly demarcated borders or set limits destabilises the oppositional categories of "original" and "copy", fundamental to the power structures of the old translation framework. For Bhabha, the third space enables an understanding of the complexity and ambivalence of the processes of change and transformation "across" cultures.

The idea of cultural translation as a trope for understanding the processes of transformation attendant on migration is explicitly articulated by novelist Rushdie 
when he defined himself, through the figure of his fictional protagonist, as "a translated man." The narrator of Shame announces: "I, too, am a translated man. I have been borne across" (Rushdie 1983, 29, emphasis in original). In a later nonfictional work, Rushdie again falls back on the Latin etymology of the word "translation" - the English word "translation" derives from the Latin word translatio, which means "to carry across" from one place or position to anotherto articulate the linguistic but also and more significantly, the cultural transfers attendant on the immigrant position. "Having been borne across the world, we are translated men", he declares (Rushdie 1991, 17).

Rushdie's implicit argument is that the act of moving both through space and across boundary lines, being "borne across", inherent in cultural translation, entails a geographical and temporal dislocation across a discernible difference, which is fundamental to the act of migration. This inevitably results in the creation of a new, or non-normative, culture and identity that is both complexly related to, yet independent of, its origins. But this "new" identity, although cut off from its "origins", also resists "smooth" transfer into the new cultural location. It remains "unassimilable" - "dis-placed" and "dis-located", but also "dis-placing" and "dislocating".

The element of unsettled and unsettling "newness" engendered by cultural translation has the potential to challenge hegemonic discourses of identity that are premised on strictures of the original and the copy/translated binary. It also has the capacity to contest any essentialised notion of national-cultural identity. In short, the "translated" or diasporic individual entering the hegemony of the dominant culture is not the only one who is changed by translation. The world or location into which he or she has been translated, or borne across, is also transformed. The migrant figure exemplifies these processes of regeneration engendered by cultural translation. As Rushdie puts it, "migrants may well become mutants, but it is out of such hybridisation that newness can emerge" (Rushdie 1991, 210, emphasis added).

This conception of cultural translation, thus, has the potential to transform the world by bringing forth something "culturally" new. From this perspective, neither the original nor its copy or translation are fixed and persisting categories. Having no stable or essential quality, they are open to being transformed and infused with fresh meaning across space and time.

In advancing his theorisation of the cultural effects of translation, Bhabha was inspired both by Rushdie and Benjamin's critique of traditional translation theory and the very idea of an essential origin. 


\section{The Ethics of Translation}

Having foregrounded the ideas of untranslatability, difference and otherness in the foregoing discussion on translation as a cultural project, I wish now to move to a consideration of the ethical project of translation. For Benjamin, the translator, like the storyteller, is "the figure in which the righteous man encounters himself" (Benjamin 1970, 109). This clearly suggests that Benjamin viewed translation as an ethical ("righteous") relationship between source text and target text, source culture and target culture. In other words, he calls on us to see translation as an ethical practice in which the original and its translation encounter each other, as equal to yet different from each other. What is privileged is not equivalence or sameness - but difference "and" equality in meaning. In other words, when one translates ethically, one actually shows respect to the otherness of the original. In a similar vein, but speaking within a different context, the philosopher of ethics, Emmanuel Levinas describes "the movement outward", which is inherent in Benjamin's conception of translation, as "the ethical impulse towards or openness to the other that effects a release from the confines of the self" (Luckhurst and Marks 2014, 184). For Levinas, as for Benjamin, the "infinite responsibility" is to the other, of "relating to the other" over and above "being oneself" (Levinas 1979, 244).

Benjamin's views on the ethics of translation are elaborated in "The Task of the Translator" - originally published as Benjamin's preface to his own translation into German of Charles Baudelaire's poem-sequence, Tableaux Parisiens-where he rejects the normative thinking that translation is a mere copy of the original, arguing instead that translation should be seen as an alternative model of difference in equality: "a translation, instead of resembling the meaning of the original, must lovingly and in detail incorporate the original's mode of signification, thus making both the original and the translation recognisable as fragments of a greater language, just as fragments are part of a vessel” (Benjamin 1923, 260).

Benjamin's plea is that we regard translation not merely as a secondary task, or simply as a medium for transmitting meaning from an original art form to another language. Instead, he urges us to view translation as a "form of its own" (ibid., 258), in much the same way that the novel is an art form and poetry is an art form. In attempting to emphasise translation as an art form in its own right, Benjamin's goal is to draw attention away from the communicative intention of translation the idea that translation has to "mean" something, that it has to communicate the original's meaning in the receiving language. 
This is a central pillar of Benjamin's (1923) argument about translation. Translation is not a derivative or subsidiary medium that is concerned with communicating or reproducing the meaning or content of an "original" work, but is a unique art form with the creative power to achieve a "pure language" (ibid., 257), by which Benjamin means a language that is able to "expre[ss] the innermost relationship of languages to one another" (255). To reinforce this point, his essay implicitly poses the question, Is communication the task of the translator? Benjamin's provocative response to this question is that a bad translation is one whose purpose is communication. Disrupting the conventional wisdom of his time that one should aim for fidelity of meaning in the receiving language, Benjamin proclaims that a good translation is one where the communication of ideas is not the intention. For him, a good translation should unsettle and disturb. A good translation does not only communicate but should communicate the incommunicable. Just as a literary text has certain incommunicable elements, a good translation - an ethical translation - has to capture that incommunicable element. It must capture the mode of signification of the original. In other words, a good translation captures not only "what is meant" but also "the way of meaning it" (257).

To shed light on the distinction he draws between meaning and the manner of meaning, Benjamin gives the example of the words brot and "pain", explaining that "what is meant is the same, but the way of meaning it is not" (257). Brot and "pain" mean or denote the same object— "bread" in German and "bread" in French-but they differ in their manner of meaning bread. For example, the German word brot incorporates the shorter word rot - meaning the colour red. This is captured in the sound of the English "bread" that similarly rhymes with the colour "red". As critics have noted, such a relationship between bread and redness is, however, absent in the French equivalents of "pain" and "rouge" (see, for example, de Man 1986, 87). The point made here is that different language systems invoke different associations of meaning, different kinds of relationship between the signifier and the signified, although they may direct our attention to the same object or "thing".

A bad translator, then, in Benjamin's scheme of things, would be one who translates the words "pain" or brot from the French and German, respectively, into "bread" in English because the three words mean the same in all three languages. These are what we would call dictionary equivalents of one another. However, for Benjamin, a good translator is one who is responsibly guided by the manner of meaning that is unique to the other language, aware that he or she must show how bread means differently in French and German. "This difference in the way of meaning permits the word brot to mean something other to a German than what the word 'pain' means to a Frenchman, so that these words are not interchangeable for them; in fact, they strive to exclude each other" (ibid., 257). 
What Benjamin attempts so meticulously to do is to draw our attention to the gap between what is meant and the way of meaning it, to what adds up to that "pure" space of "otherness" in the relationship between languages. Although in the three individual languages - French, English and German - taken as a whole the different words (pain, bread and brot) mean "one and the same thing" (ibid., 257), as fragments of a pure language these words mean differently. "Pure language", then, is "achievable not by any single language but only by the totality of their intentions supplementing one another" (ibid., 257). It is this space of otherness, then, of colliding and jostling significations, as it were, when different language systems and their modes of intention encounter and supplement each other with their difference that Benjamin holds up as "pure language". In other words, otherness is essential in order to attain "pure" space. This otherness is not construed in adversarial or absolutist terms but as a supplementary difference that is vital to attain "pureness" of language. Within the parameters of this argument, a pure language is the domain of the unstable, without common scripts or uniform modes of intention, a space of "untranslatability" and absence or postponement of meaning and therefore ultimately and also paradoxically, revealing "a greater language" of non-exclusion. This "pure language" exists on the level of an abstraction and thus of course is impossible to attain, yet as an idea(l) it is to be valued and pursued.

The question then arises: "What insights can Benjamin's poetics of ethical translation and pure language reveal for postcolonial societies?". Indeed, once we discern that modes of intention can mean the same thing "differently" we begin to understand how the cultural "other", whose signifying mode differs from our own, could pose a challenge to our own linguistic and conceptual universe, to how we reference the world. Yet, this "other" is to be valued for it is only by incorporating its different mode of intention into our own language and cultural system that our language can attain "pureness". The ethical translator, thus, is one who does not flatten or smoothen out the "difference" introduced into the system by the cultural "other" but who uses this discrepancy (that is, how the manner of meaning can signify differently) to push at the limits of our language so to make it adhere as closely to the foreign text as our language will allow in order to capture the otherness of the foreign language. This then, for Benjamin, is the task of the translator - not to communicate the meaning of the original but to demonstrate the relations with otherness that exists between languages.

It is here that the purpose of Benjamin's ethical project of translation can be most closely aligned with the politically emancipatory goals of cultural translation. Indeed, it is from Benjamin's deconstruction of traditional translation theory that Bhabha creates a new framework, a new language and a new articulation and understanding of minority positions within the politics of the nation-state. As 
pervasive as the forces and discourses of globalisation are, they cannot be used to ignore or underestimate how national culture and identity continue to be reasserted around the principles of normative multiculturalism. For this reason, Bhabha's postcolonial paradigm of cultural translation urges us to think about culture and the relations between cultures beyond the idea of prior cultural identities or of cultures having discrete points of origins. For this reason, he asks that we differentiate between "cultural difference", which enacts change and transformation to national cultures and "cultural diversity", which reproduces the pluralist colonialist logic in nationalist ideology and discourse.

The state-driven discourse of multiculturalism in Malaysia, for example, advocates non-conflictual "race relations" among the nation's various cultural communities in terms of the trope of muhibbah or so-called "harmonious" multicultural cohabitation. This is because the ruling elite, like other standard proponents of multiculturalism, want to understand cultural translation always as an "intercultural" phenomenon, which in Malaysia amounts to "inter-ethnic" or "interracial" interaction and co-existence. This received narrative of multiculturalism is favoured by hegemonic discourses because the notion of "inter" that operates in formulations such as "inter-cultural" leaves unchallenged the hierarchy and power relations that undergird cultural diversity or plural society's conception of prior or fixed cultures. Instead, Bhabha advances the concept of cultural difference in terms that resonate with Benjamin's "pure" space where neat categorisations and binary divisions between original and copy, source culture and target culture are undone. He believes that cultural difference, which he regards as a synonym for the transgressive hybridity of cultural translation and the third space, is in itself politically subversive. By traversing neat demarcations, like Rushdie's bordercrossing migrant, the idea of culture embedded in cultural difference points to a space of flows that erases binary differences between cultures and unsettles power relations to generate new forms and meanings of social relations and cultural identities. Thus, the "third" space does not represent some facile interaction of two categories or cultures, as implied by the multicultural platitudes of muhibbah and "tolerance", but "entertains difference without an assumed or imposed hierarchy" (Bhabha 1994, 4). In short, the third space of cultural difference produced by cultural translation contests cultural diversity's legitimation of a narrow and rigidly-defined notion of what it means to be "Malaysian".

For Bhabha, the notion of "untranslatability," which refuses reductive interactive co-existence and universalising impulses, is a point of resistance, a negation of complete and coercive assimilation or integration. It resists the search for absolute equivalence as envisioned and desired by the state as the translator between the nation's ethnic communities through its cultural policies (for a discussion of the 
role of the state as translator, see Gabriel 2011). A multiculturalism based on cultural difference is therefore more culturally inclusive and emancipatory than the one based on cultural diversity. In short, the third space of difference as a site of cultural translation produces not an exact match but a new text of identity and culture.

These ideas can be illustrated by critically evaluating the concept of Bangsa Malaysia (Malaysian Race/Nation) from the perspective of the state and that of the nation's people. Former Prime Minister Tun Dr Mahathir Mohamad, when introducing the idea in 1991, defined Bangsa Malaysia as "an inclusive national identity for all inhabitants of Malaysia [...] of all colours and creeds" and as "people being able to identify themselves with the country by speaking Bahasa Malaysia (the Malay language) and accepting the Constitution" (Mahathir 1991). Although Mahathir makes a potentially empowering move by invoking "race" in terms of an all-inclusive "Malaysian race" (bangsa Malaysia) rather than the standard MCIO ("Malay", "Chinese", "Indian", "Other") race paradigm, his definition falls short of an emancipatory conception of race and national identity. The language with which he invokes Bangsa Malaysia as "an inclusive national identity" still takes recourse to the formal signifiers of nation-hood (National Language) and legal citizenship (Constitution). Such a "top down" or state-led discourse draws attention to the standard or normative signifiers of national identity while leaving untouched and unchallenged, the hierarchies underpinning the cultural signifiers of national identity. That is, Malaysians "of all colours and creeds" are still viewed as people remaining in their own racial "silos", who have not been transformed or influenced "culturally" by "other" ethnic communities. The state's articulation of Bangsa Malaysia as "an inclusive national identity" recalls the standard multiculturalist discourse of cultural diversity rejected by Bhabha.

From "bottom up" perspectives and their agency, however, the Bangsa Malaysia concept introduced into public discourse by the state offers us a way to theorise the national imaginary as a newly translated text where Malaysian national identity initially defined and delimited by a "Malay" target identity by a hegemonic state enters into a supplementary relationship with "other" identities and cultural genealogies, those constructed as "immigrant" or, in popular parlance, as pendatang (newly arrived or newcomer). In this (re)formulation, binary assumptions about the target and source culture, about the authentic original or "indigenous" and the debased translation or pendatang are called into question, signalling the impossibility — and undesirability — of absolute sameness or perfect equivalence. In this space of cultural translation, what it means to be Malaysian is kept alive and open to new meaning as all the nation's "races" and cultures and their modes of intention, encounter each other and reform and transform 
each other, as supplements of each other. This is the third space of the location of Malaysian culture. Bangsa Malaysia, thus located, is a "pure space" of newness that is predicated on the principles of supplementary (and not absolutist) difference and equality.

The utopian idea(1) of Bangsa Malaysia as a new text of national identity brings to mind what Jacques Derrida calls the double bind of translation - that translation is both impossible and necessary. Translation is impossible because of the ultimate failure of semantic and cultural transference, since one has to communicate the incommunicable, while it is necessary because it compels us to strive to address the value of the other. After all, at its most fundamental level, translation offers us a way to understand what to make of our confrontation with alterity. As Octavio Paz has asked, "What is translation if not an encounter with 'otherness'?" (as quoted in Honig 1985, 159).

Indeed, translation was a very important theme in Derrida's engagement with the oppositions and hierarchies underpinning meaning-making. In his 1985 essay, "Des Tours de Babel", arguably his most influential text on translation, Derrida asks, "What does translation aspire for?". It aspires for the possibility of what in Benjamin's poetics of ethical translation is described as "pure language". Derrida, however, calls it "the language to come". This shares resonances with his coinage of the term différance, which derives from the French verb differer - to differ and to defer (postpone) - to characterise how meaning is created or produced rather than as simply existing a priori in any system. Differance is the notion that words and signs can never fully summon forth what they mean, but can only be defined through their difference from other words. In short, Derrida's point was that meaning is not inherent in the signifier itself, but exists in a network of differences, in relation to "other" things. Differrance, then and the idea of meaning as both differing and deferred implicit in it, challenges the fixed binaries that stabilise meaning by always moving to encompass "other" or supplementary meanings. In short, without the supplementary other, so important also in Benjamin's pure space, there can be no meaning.

Through his "language to come"- - a language which is not here yet, which has not emerged yet like Benjamin's "pure language"-Derrida refers to a deferred point in time, one that aspires to circumvent the tyranny of the "here and now". This endlessly deferred time opens itself to the future (l'avenir), or to venir (to come) or more precisely to viens (come) - that fundamental gesture of hospitality. The futurity, or the possibility of an open and deferred future, implied in the expression l'avenir and venir, prepares the way for "newness" and opens up a space that points to survival and hope. Translation as an ethical exercise, for Derrida as for 
Benjamin, thus allows different languages to talk to one another as supplements of one another - as each other's "other" - to try to arrive at a pure language. Only this can undo the logocentric, monologic and monolingual hegemony of the Tower of Babel.

A good translation - an ethical translation-is to put an end to jingoisms, chauvinisms and xenophobia of all kinds. Benjamin (1923, 261-262) asserts:

Our translations, even the best ones, proceed from a wrong premise. They want to turn Hindi, Greek, English into German instead of turning German into Greek, Hindi, English. [...] The basic error of the translator is that he preserves the state in which his own language happens to be instead of allowing his language to be profoundly affected by the foreign tongue. [...] [Rather,] he must expand and deepen his language by means of the foreign language.

The well-known translation scholar Lawrence Venuti agreed in principle with Benjamin. Venuti also believed strongly that a translation, far from reading fluently and without any awkwardness as if it were an original, should bear the visible sign of its translatedness (Venuti 2004). The idea is not to look for equivalents in the target cultural area but to preserve the foreignness of the original text, to let it enter our domestic space rather than to force it to assimilate or yield to the cultural power and dominance of the receiving culture. Only then can translation be an equal cultural exchange.

The ethical project of translation thus draws attention to minority discourse. The reader must make the ethical effort to understand the "other", to meet the other, the one who is culturally different, on equal terms. The value of the other lies precisely in its otherness. This means that the reader enters the world of the other, rather than the other way around. Translation's ethical responsibility is to effect this moment of estranging exchange, to allow the reader to engage with the unfamiliarity of the other.

A good translation, then, does not domesticate the source. This is to say that a good translation seeks to infect or contaminate the target text with the otherness of the original. The point of translation is lost if alterity is lost. This idea of translation does not allow the target text to retreat into a cocoon; it compels the receiving language or culture to deal with the reality of the other. This, as I have mentioned, is necessary for translation to serve as an ethical project, as an offer of hospitality, one which enables our language to be permeated with the discourse of the other. 
Furthermore, when the etymology itself of "translation" is considered - it literally means to "carry across" - translation can be seen to be a verb, a deed, the act of transferring across. This brings us to the questions, what kinds of borders are being crossed? And, as importantly, what is it that is being carried? These questions bear reflection and contemplation. However, what is of greater significance to me in this context is that the notion of carrying, implicit in the word's etymology, has a gestational or maternal sense, suggesting that translation cannot be a dispassionate act or task.

The maternal or gestational sense inherent in the act of carrying across is explicated in Stuart Hall's (1990) seminal article, "Cultural Identity and Diaspora". In this essay, Hall offers two different ways of thinking about cultural identity. The first is an essentialist identity, which emphasises the similarities amongst a group of people. Hall argues that although the wished-for coherence of this identity can help provide a sense of solidarity and commonality to dispersed and marginalised groups and inspire anti-racist activism, it cannot account for the profound ruptures caused by colonialism. His second definition takes these discontinuities on board and emphasises the differences as well as the similarities amongst an imagined cultural group. Although Hall's conjecture focuses on cultural identity reformations within the context of diaspora and its temporal and geographical disjunctions, I suggest that it is also informed by the underlying idea that diasporic people are alwaysalready translated people. The idea of diasporic people-subjects being borne across from what he calls "the mother" is implicit in Hall's illuminating suggestion that the relationship of the child (the translation) to its mother (the original) only begins "after the break". As Hall $(1990,226)$ puts it, "The past continues to speak to us. But it no longer addresses us as a simple, 'factual' past, since our relation to it, like the child's relation to the mother, is always-already 'after the break"'.

The argument is that diaspora as a discursive and ideological formation only comes into effect after the break, as a result of that break, of that rupture of time and space. And because discontinuity, dislocation and displacement have happened, the past - that fixed point of origin before the break - can never ever be returned to. Postcolonial subjects can never go back whole to the beginning, to "be one again with the mother" (Hall 1990, 236). It is this "break", the fragmenting of the relation between the mother and the child, which makes new meaning and identity possible by preventing any arbitrary closure of meaning or closing of the gap.

Hall's progressive conception of diaspora as our open and contingent futures overlaps with Benjamin's and Derrida's supplementary imperative of translation. Diasporic subjects will not fit into their originary past because they have left the Lacanian realm of the imaginary and become new kinds of subjects in the time 
"to come", the domain of the deferral of meaning. That is to say, translation does not merely forward the legacy of the original; the "copy" has its "own" life in the diaspora. As translated "texts" diasporic subjects may never fully replicate the original; they are their own creative act, their own "afterlife," for translations come "after the original" (Benjamin 1923, 254, emphasis added).

\section{Conclusion}

I have sought to connect in this article the ethics of translation with the project of cultural translation and diasporic identity formation. More specifically, I have tried to show how translation as an ethical project can help us rethink our relationship to our cultural other. In doing so, I have taken my cues from the theoretical reflections of Benjamin, Hall, Derrida and Bhabha, as well as the ideas of novelists such as Rao and Rushdie, also seeking to locate their ideas' inter-relatedness so as to open up a shared space of intervention for cultural translation. Hall's clarion call of "after the break" [emphasis added] gestures to that vital sense of diaspora's belatednessDerrida's supplement, Benjamin's "afterlife" of the original, Rushdie's mutant "newness"- that is produced and reproduced by the cultural and ethical project of translation. It affirms as vital the visible signs of "translatedness" - of difference, dissonances and dividedness of identity, so integral to progressive conceptions of national culture, as exemplified by a people-driven translation of Bangsa Malaysia.

In elaborating his views on the necessary and inevitable reformations of cultural identity, Hall conceptualises for us a different sense of our relationship to the past, to our beginnings, pointing to a re-constitution of the "intended meaning" of the "original" cultural identities through which we were brought into being. From this perspective, diasporic cultures cannot simply "return to the original" since they have, on entering diaspora, also entered the realm of the symbolic, into which they are released from the old circuit of meaning-making, from already-written or prescribed codes and modes of intention, to enter estranging newness, into the indeterminate but crucial realm of Benjamin's "pure space", Bhabha's "third space" and Derrida's "future to come". This symbolic realm of identity and representation is the space where cultural and national meanings and systems collide and cohere, without erasing difference, remaking themselves through their encounter with otherness. This symbolic "after" space of diaspora, where meanings are deferred and continually renewed through an active and ongoing negotiation with difference, is a space of overlap and flux, where cultural meanings and identities are deliberately left unfinished, gesturing to the future, to the unfinishedness of the time to come.

The ethical imperative, then, is for us to cross our boundaries so as to reach out to the "other" entering our national and cultural community, to offer hospitality to 
our "untranslatable" other. Far from obscuring or effacing the foreign other, our ethical responsibility is to move out of the familiarity and comfort of the insular cocoon of the self so as to encounter and embrace the other, to accept the other "as different but equal" - to touch and be touched by difference, to transform the other and to be transformed by the other. What is valorised, then, in cultural translation is not linguistic proficiency, but cultural empathy. This message of our mutual interrelatedness is the cosmopolitics of knowing and relating to the other in our globalised, networked century. This is the ethical project of reaching out to the other. These are the powerful egalitarian and emancipatory political possibilities offered by cultural translation. This then is the way we break free from the single, hegemonic tyranny of "one race, one language, one nation".

\section{References}

Bassnett, S. 1980. Translation studies. London/New York: Routledge.

Benjamin, W. 1996. The task of the translator (1923). In Selected writings volume $11913-$ 1926, eds. M. Bullock and M.W. Jennings, 253-263. Cambridge/Massachusetts/ London: The Belknap Press of Harvard University Press.

. 1970. The storyteller (1936). In Illuminations, edited and with an introduction by H. Arendt and translated by H. Zohn. London: Jonathan Cape.

Bhabha, H. 1994. The location of culture. London/New York: Routledge.

de Man, P. 1986. Conclusions: Walter Benjamin's "The task of the translator". In The resistance to theory, ed. P. de Man, 73-105. Minneapolis: University of Minnesota Press.

Derrida, J. 1985. Des tours de Babel. In Difference in translation, ed. J.F. Graham, 165207. Ithaca/London: Cornell University Press.

Gabriel, S.P. 2011. Translating Bangsa Malaysia. Critical Asian Studies 43(3): 349-372. https://doi.org/10.1080/14672715.2011.597335

Hall, S. 1990. Cultural identity and diaspora. In Identity: Community, culture, difference, ed. J. Rutherford, 222-237. London: Lawrence \& Wishart.

Honig, E. 1985. The poet's other voice: Conversations on literary translation. Amherst, MA: University of Massachusetts Press.

Hyde, G. M. 1993. The Whorf-Sapir hypothesis and the translation muddle. Translation and Literature 2: 3-16. https://doi.org/10.3366/tal.1993.2.2.3

Lefevere, A., ed. 1992. Translation, history, culture: A sourcebook. London/New York: Routledge.

Levinas, E. 1979. Totality and infinity: An essay on exteriority. Translated by A. Lingis. The Hague: Martinus Nijhoff. https://doi.org/10.1007/978-94-009-9342-6

Luckhurst, R. and Marks, P., eds. 2014. Literature and the contemporary: Fictions and theories of the present. New York/London: Routledge.

Mahathir Mohamad. 1991. The way forward: Vision 2020. Retrieved from http://www. wawasan2020.com/vision/index.html (accessed 23 March 2020). 
Niranjana, T. 1992. Siting translation: History, post-structuralism and the postcolonial context. Berkeley, CA: University of California Press. https://doi. org/10.1525/9780520911369

Rao, R. 1938. Kanthapura. London: G. Allen \& Unwin.

Rushdie, S. 1991. Imaginary homelands: Essays and criticism, 1981-1991. London: Granta.

1983. Shame. London: Picador.

Tymoczko, M. 1999. Translation in a postcolonial context: Early Irish literature in English translation. Manchester: St. Jerome Publishing.

Venuti, L., ed. 2004. Translation studies reader. 2nd Ed. New York/London: Routledge. 